\title{
The Practice of Urban Renewal Based on Creative Industry: Experience from the Huangjueping Creative Industries in Chongqing - China
}

\author{
Liu Dong ${ }^{1} \&$ Mustapha Haruna ${ }^{2}$ \\ ${ }^{1}$ Sichuan Fine Art University, China \\ ${ }^{2}$ Faculty of Science and Economics, Universidad Austral de Chile, Valdivia, Chile \\ Correspondence: Mustapha Haruna, SPRING Program Chile, Faculty of Science and Economics, Universidad \\ Austral de Chile, Valdivia, Chile. E-mail: makolbugri@yahoo.com
}

Received: February 15, 2012 Accepted: March 31, 2012 Online Published: May 1, 2012

doi:10.5539/jsd.v5n5p101

URL: http://dx.doi.org/10.5539/jsd.v5n5p101

\begin{abstract}
Along with urbanization, the cities in China are faced with a series of adjustments such as industrial transformation, economic growth, and organic update. The Huangjueping creative industry (based) in Chongqing developed an industrial cluster built around arts relying on the College and using its vacant resources such as warehouse and factory buildings among others. The industry emphasizes their presence with cultural features and renews the urban blocks with simple and rich distinctive forms. This paper examines the policy and process of urban transformation using arts, culture and creativity. We found out that culture and creativity can modify urban fabric using arts in a process of urban renewal, and creating industrial clusters. We also found out that graffiti can be used to create unique urban traits and distinctiveness, and that industrial clusters are more effective in cultural and creative industries compared to other local economic development activities. The paper concludes that focusing policy on utilizing a city's uniqueness provides a new perspective to developing sustainably.
\end{abstract}

Keywords: industrial cluster, creative industry, urban renewal, huangjueping

\section{Introduction}

The value of culture to economic and structural transformation is not easily determinable. This has made the argument for additional public funding and investment in the area of cultural industries difficult. Yet, it is known to be contributing to employment generation and social identity among several benefits (see, for instance, O'Connor, n.d.). The United Nations Educational, Scientific and Cultural Organization (UNESCO) through the Global Alliance for Cultural Diversity program note that, creative industries via culture has become an important pillar of modern day post-industrial knowledge-based economies (UNESCO, n.d.). They include the creation and production of intangible cultural products and services such as cinematographic and phonographic materials, printing, publishing, multimedia, crafts and design etc (Ibid.). The broader dimension of all the cultural industry activities including more advanced artistic components and creative activities is what constitutes the creative industry (see details in section 3.1).

Well developed clusters of cultural and creative industries provide opportunities for small businesses (especially cultural industries) to overcome barriers to competition (using internal linkages), and for promoting local economic development. According to Porter (2000), businesses in industrial clusters are linked by commonalities and complimentarities in a geographically proximate unit (Porter, 2000). Such is the case of the creative industry in the Chinese city of Huangjueping.

Huangjueping city are only 5.08 square $\mathrm{km}$ and is located southeast of Jiulongpo district of Chongqing (southwest China). The city has over 69 large or medium-sized enterprises including Chongqing power plant and institutions such as the Sichuan Fine Arts University, Chongqing Electric Power College, and 26 storage companies among others. With the transformation of the district economy and the reorganization of urban space in Chongqing, Huangjueping as the transport and industrial base was left with a large number of vacant warehouses. The city also had a strong artistic atmosphere because of the nature and influence of the Sichuan Fine Arts University in nearly 70 years. There are more than tens of thousands art university entrance examinations taken by students every year. These students are made up largely of artists. There are also dozens of large and small sculpture factories that form the premise for the thriving creative industry. The Huangjueping graffiti Art Street was opened and has hosted the grand Chinese graffiti festival since June 2007. This marked the beginning of the 
Huangjueping creative industrial base. At the end of 2007, the Jiulongpo District Government formulated the development direction of Huangjueping as: developing the art resources of Sichuan Fine Arts University greatly using idle spatial resources in the region, developing creative industrial clusters, supporting the formation of the municipal creative industries and the national arts tourism area with the Fine Arts University as the core and Huang Jue Ping Art Street as the central axis.

\section{Methods}

\subsection{Materials}

This paper is both theoretical and empirical. It uses theoretical foundations of urban renewal and creative industry to position and provide a conceptual base for the practical experience in the city of Huangjueping, Chongqing Municipality, China. The theoretical aspects include document reviews and discourse analysis of media and public discourse.

Primary data was collected through interviews with state agencies, the municipality of Chongqing and the creative industry project contact persons. Other experts in academia particularly the Sichuan Fine Art University also provided insights into the design and practice of the creative industry models in China. A total of two months in 2010 was used to collect and collate the views and documents used in the analysis and presentation contained herein.

The analysis involved mainly statistical tabulations of the views and data collected, and interpretations of the statistics. Details of the findings are summarized and presented under subheadings in section 3 titled 'results'.

\subsection{Area Description}

China's economic success in recent times has attracted international attention leading to many researchers choosing case studies in what has become the worlds' most successful communist country. The decision to present perspectives (of this paper) from there can therefore be treated as a state of the art. The theme is particularly important in the context of China as many are looking up to learning from the magic of economic and social transformation in the world's most populous country.

Chongqing is one of the big cities in Southwest China. It is also one of the five national central cities of the People's Republic of China (PRC). The municipality is one of China's four direct-controlled municipalities (the other three are Beijing, Shanghai and Tianjin), and the only such municipality in mainland China. Created in 1997, the municipality of Chongqing succeeded the sub-provincial city administration that was part of Sichuan Province. In November 2010, the municipality had a population of 28.9 million with an urbanized area of 7 million (Chongqing Municipality, 2011). The municipality has 19 districts, 15 counties, and 4 autonomous counties. With an area of 82,401 square $\mathrm{km}$, Chongqing is the largest direct-controlled municipality (Ibid).

\section{Results}

\subsection{Creative Industries}

The term creative industries encompass a broader range of activities which include the cultural industries plus all cultural or artistic production, whether live or produced as an individual unit. The creative industries are those in which the product or service contains a substantial element of artistic or creative endeavour and include activities such as architecture and advertising. Australia issued the first national cultural development strategy, put forward the concept of establishing a "country of creative industries" ruled by related development policies, and pushed by the concept of creative industries in 1994. The government then came out with a clear concept of the cultural industries combined with the creative industries in the late 1990s (Qiang, 2007).

Later, the British found prospects and value in creative industries and put forward creative industries at the core of developing British economy in 1997 by establishing the UK Creative Industries Task Force. The group issued the Creative Industries Mapping Document in 1998 which first explained explicitly the concept of creative industries. According to the document, a creative industry encompass individual creativity where skill and talent become the instruments for creating wealth and increasing potential employment by means of developing and using intellectual property rights (Drake, 2003). The common forms of art activities in this area are: Advertising, Antiques, Architecture, Crafts, Design, Fashion, Film, Leisure, software, Music, Performing Arts, Publishing, TV and radio, etc. (Ibid).

After 10 years of development, creative industries theory had made great progress. Many experts and scholars brought out original ideas on the concept of creative industries and made outstanding contributions to the theory and practice of creative industries. They include the British economist John Hawkins in his books the Four Global Scenarios on Information, the Creative Economy: how people make money from ideas, and 
Collaboration and Ownership in the Digital Economy (published in 1997, 2001, 2003) respectively.

American cultural and economic theorist Richard Caves (in his article 'Contracts between Art and Commerce') documented a wide range of commercial interactions across the creative industry. It includes visual and performing arts, movies, theatre, sound recordings, and book publishing (Caves, 2003). There are other scholars such as Chinese Peking University professor Ji-ci Wang, Beijing Municipal Science and Technology Research Institute associate Jingcheng Zhang and so on. Although the concept of creative industries varies in different countries, it has been accepted generally in most countries as above.

Though it started late, the creative industry developed rapidly in mainland China. Shanghai, Shenzhen, Beijing and other cities promoted the development of creative industries actively and formed a number of groundbreaking creative industry bases. For example Beijing had 798 of such enterprises. In 2008, cultural and creative industries in Beijing, Shanghai and Shenzhen grew by 19\%, 20\% and 22\% respectively (Yanfei et al., 2010). The value of the industry reached about $€ 3.3$ billion at the end of 2010 in Chongqing representing an increase of nearly $25 \%$ from the previous year. There have also been built 25 creative arts industry bases such as Hongyadong, BaGuoCity, ShiMei animation base, 501 bases etc (Chongqing Municipal Bureau of Statistics, 2011). In Chongqing, the Huangjueping region has five of such bases.

\subsection{The Spatial Renewal and Industrial Planning of Chuanmei Creative Valley}

Huangjueping is relying on the university to transform the teaching and research ability of the universities in the area into an industrial development park, and make the warehouse and plants around it more useful. It has created a new form of interaction among academics, the university, industry and government. This is however yet to manifest itself in the spatial organization of ChuamMei valley. It is still young to be termed as a failure and might just need some more time to make significant impacts.

\subsubsection{Project Positioning}

The layouts of the creative industries comprise one core, one axis and one ring in the Huangjueping region. The core is the Sichuan Fine Arts University, the axis is Huangjueping Graffiti Street, and the ring is the creative industries cluster belt around the core of Sichuan Fine Arts University with a radius of approximately $1 \mathrm{~km}$. Since most of the teaching units of Sichuan Fine Arts University had immigrated into Chongqing Higher Education Mega Centre (outside the area), they only have some teaching units such as Commercial Arts Department, Applied Fine Arts Department, Continuing Education Department etc. and about 3,000 students in Huangjueping. JiuLongPo district set up a project group to re-plan and manage the region and called this area the ChuanMei Creative Valley (Sichuan Fine Arts University Creative Valley) in March 2010.

The project components include: deepening the rich cultural heritage of art and humanities; good cultural ecology and an excellent cultural and creative atmosphere in Sichuan Fine Arts University (Huangjueping Campus) taking advantage of teaching, research and experiment space resources of Huangjueping areas, and combining the planning and renewal of factories, warehouses as well as buildings in the area. It is also developing large-scale industrial clusters covering film, television animation, painting, sculpture, landscape architecture, art design, crafts and other forms of arts to become the largest cultural industrial park in the southwest region. The project is seeking further to build the Sichuan Fine Arts University Creative Valley as a government-led, market-oriented, multi-format, industrially-clustered, and a distinctively national creative industrial base.

\subsubsection{Planning the Creative Industry}

Sichuan Fine Arts University Creative Valley has four industries: arts exhibition, arts commerce, arts creation, and arts education. Art education industries have 10 years of history in Huangjueping. There are hundreds of fine art schools and training institutions such as the Sichuan Fine Arts University and the 307 arts and design training centres among others. The Art exhibition industry has since begun to take shape. It has nearly 10 large scale exhibition Museums including the Chongqing Art Museum, Sichuan Fine Arts University Gallery, and over 501 art galleries in Huangjueping. The Art include fine art works, business, art books, supplies, and creative cultural products.

An annual Art festival is held every June at the Sichuan Fine Arts University. This festival attracts many large auction institutions coming from as far and big as Beijing and Shanghai for example, art lovers and the general public who go for exhibitions or to purchase art works. For promoting the art works market, Huangjueping set up Chongqing contemporary art business centre in 2010. Art creation industries have been weak for some time now. But efforts are been made to make the cultural and creative industries the focus for the future development of Huangjueping. 
The planning of ChuanMei Creative Valley had nine design professionals, 31 categories of cultural and creative industries including visual arts design, industrial product design, landscape architecture, and planning. The total area covered is more than 40,000 square meters making it the largest of the four major industries (see Figure 1.).

Table 1. Site planning of huangjueping creative industries

\begin{tabular}{|c|c|c|c|c|}
\hline \multicolumn{2}{|l|}{$\begin{array}{l}\text { Project } \\
\text { categories }\end{array}$} & Name of project content & Location (previous) & $\begin{array}{l}\text { Building } \\
\text { area }\left(\mathbf{m}^{2}\right)\end{array}$ \\
\hline \multicolumn{2}{|c|}{$\begin{array}{l}\text { Management } \\
\text { centre }\end{array}$} & $\begin{array}{l}\text { Huangjueping Creative Industry Park } \\
\text { Management Centre }\end{array}$ & $\begin{array}{l}\text { Administration } \\
\text { building }\end{array}$ & 2,500 \\
\hline \multicolumn{2}{|c|}{ Culture leisure } & Huangjueping Creative Industry Park Hotel & Expert guest Hotel & 2,000 \\
\hline \multicolumn{2}{|l|}{$\begin{array}{l}\text { Culture } \\
\text { education }\end{array}$} & $\begin{array}{l}\text { Commercial Art faculty; Arts Training Centre for } \\
\text { Professional Examinations; Animation Training } \\
\text { Centre; Software Training Centre; Animation } \\
\text { Design Training Centre; Vocational Training } \\
\text { Centres of Contemporary Art and Design; } \\
\text { Designer Training and Examination Centre }\end{array}$ & $\begin{array}{l}\text { Continue education } \\
\text { building; The No. } 1 \\
\text { building; Affiliated } \\
\text { school teaching } \\
\text { building }\end{array}$ & 21,650 \\
\hline \multicolumn{2}{|r|}{1} & $\begin{array}{l}\text { The Tank-warehouse-Chongqing Contemporary } \\
\text { Arts Centre; Chongqing Humanities Social } \\
\text { Sciences Research Centre; Mixed Materials and } \\
\text { Technology Development Centre; Media } \\
\text { Information Research Centre; Architectural Art } \\
\text { and Form Research Centre; Urban Public Art } \\
\text { Research Centre; Chongqing Tourism Product } \\
\text { Research and Development centre; etc. }\end{array}$ & $\begin{array}{l}\text { The Tank-warehouse, } \\
\text { Chongqing } \\
\text { Contemporary Arts } \\
\text { Centre; Sculpture } \\
\text { Teaching Building; } \\
\text { The Experiment and } \\
\text { Teaching Building }\end{array}$ & 25,540 \\
\hline \multirow[t]{3}{*}{$\begin{array}{l}\text { cultural } \\
\text { creativity }\end{array}$} & 2 & Design Studios and Design Firms & $\begin{array}{l}\text { Studio in General } \\
\text { Building }\end{array}$ & 5,280 \\
\hline & 3 & $\begin{array}{l}\text { More than } 100 \text { Students Self-employed Art } \\
\text { Studios }\end{array}$ & $\begin{array}{l}\text { The No. } 2 \text { Teaching } \\
\text { Building }\end{array}$ & 4,977 \\
\hline & 4 & Creative sharing platform & The Library & 5,409 \\
\hline \multicolumn{2}{|c|}{ Culture business } & Art Goods and Articles of Fine Arts Market & Huangjueping Street & 20,000 \\
\hline \multicolumn{2}{|l|}{$\begin{array}{l}\text { Cultural } \\
\text { exhibition }\end{array}$} & $\begin{array}{l}\text { Cultural Creative Exhibition, Business } \\
\text { Negotiation, Sales Hall; Chongqing Art gallery, } \\
\text { Sichuan Fine Art University gallery (Small } \\
\text { gallery); } 108 \text { galleries. }\end{array}$ & $\begin{array}{l}501 \text { Warehouse gallery, } \\
\text { Chongqing Art gallery } \\
\text { etc. }\end{array}$ & 8,084 \\
\hline
\end{tabular}

Source: Professor Wang Lidua (Project Leader) ChuanMei Creative Valley project sponsored by the Sichuan Fine Art University 


\subsubsection{Site Planning}

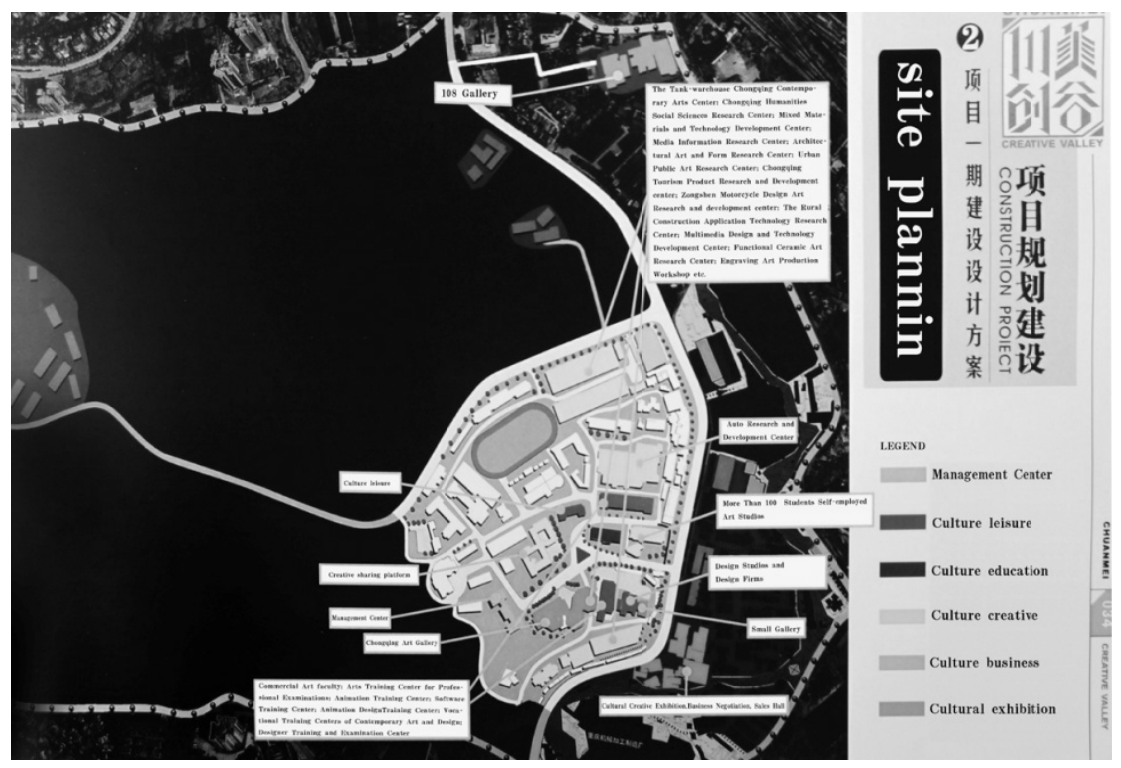

Figure 1. Site and Industrial Planning, a research project of ChuanMei Creative Valley sponsored by the Sichuan Fine Art University.

Source: Project Leader, Professor Wang Liduan, 2010.

The planned area of Huangjueping creative industry base is 140 hectares and will be completed in three phases. The renewal of the Sichuan Fine Art University and Huangjueping streets is the first phase and also the core of the project. After the preparatory works are complete, the Sichuan Fine Art University will change its educational function and become a creative industry. Meanwhile, the original university is divided into six areas namely: management centre, cultural education, cultural leisure, creative industry, cultural exhibition and cultural business areas (see Figure 1 above). The total building area is approximately 95,440 square metres.

\subsection{Urban Space Renewal in Huangjueping through Arts}

Urban renewal is a necessary adjustment and change with planning to the areas that were no longer fit for the modern urban social life in the city. Plans to alter the urban environment and enhance the city's vitality were made. Huangjueping' urban renewal area is more about the space functional conversion and the long-term local art characteristics protection in order to realize its sustainable development objectives which include growth with minimal destruction to the natural environment. The pictures (Figures $2 \& 3$ ) show various initiatives and projects been undertaken as part of the larger industry initiative. 


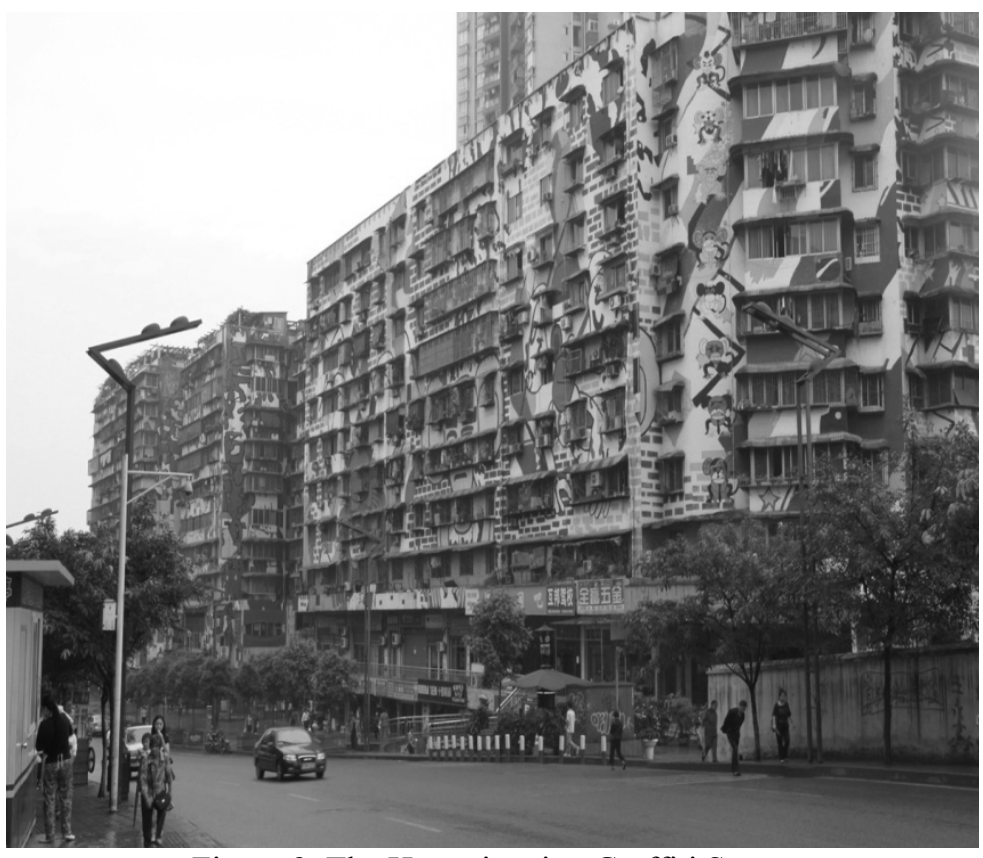

Figure 2. The Huangjueping Graffiti Street

Source: taken by Author.

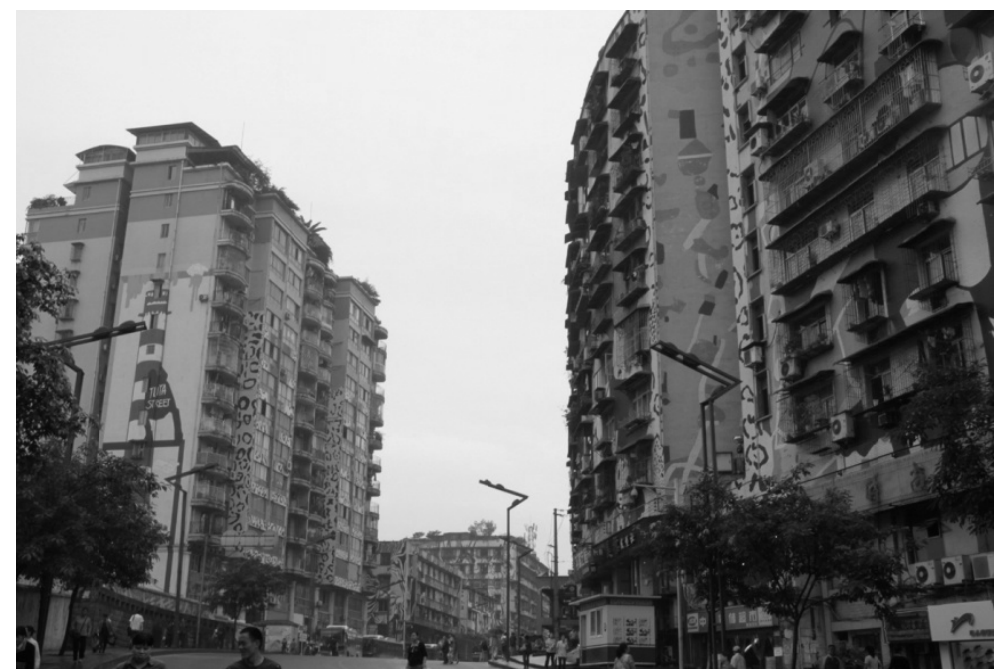

Figure 3. The Huangjueping Graffiti Street

Source: taken by Author.

\subsubsection{Block Renewals}

The total length of the Huangjueping street is $1.25 \mathrm{Km}$ (Figure 2). The renewal of the street began in 2007 and it was combined with the widening transformation of YangJiu road. The renewal was seen as important to reduce the buildings' demolition. Because there were a lot of disorders in the architectural style i.e. uneven height and different ages, the renewal used the graffiti art style and made the old streets much more art and fashion. The design is aimed at strengthening the visual appearance of buildings, maintaining and emphasizing the unique art of Huangjueping. It is also inheriting the historical context of the streets.

Secondly, data from the municipality of Chongqing indicate that the renewal has unified 187 commercial stores advertising with the same style and material along the street at the same time that the transformation of the facade; repaired and replaced wall canopy, doors, and windows; redesigned the overall lighting of the graffiti buildings and throughout the street. The renewal also saw the reconstruction of 37 buildings with a total area of about 50,000 square metres while the street has remained the longest graffiti street in the world. 
Further, emphasis is placed on opening and closing of the street space especially the vegetable market area formed a spacious street space and had become an important public place in the Huangjueping region especially after all temporary buildings were removed. The night market is very booming with a unique landscape. The street also added some flower beds and tree pools and set the artistic stool where important leisure spaces were formed for the public. In addition, the street replaced the entire pavement and added three small green stripes in small sculptures.

Huangjueping block renewal was not only for reconstructing space but also adjusting the space function of part or the whole of buildings. In order to create the creative industrial clustering, the renewal adjusted about 6,000 square metres of commercial stores for the cultural and creative companies (see for example, Figures $3 \& 4$ ).

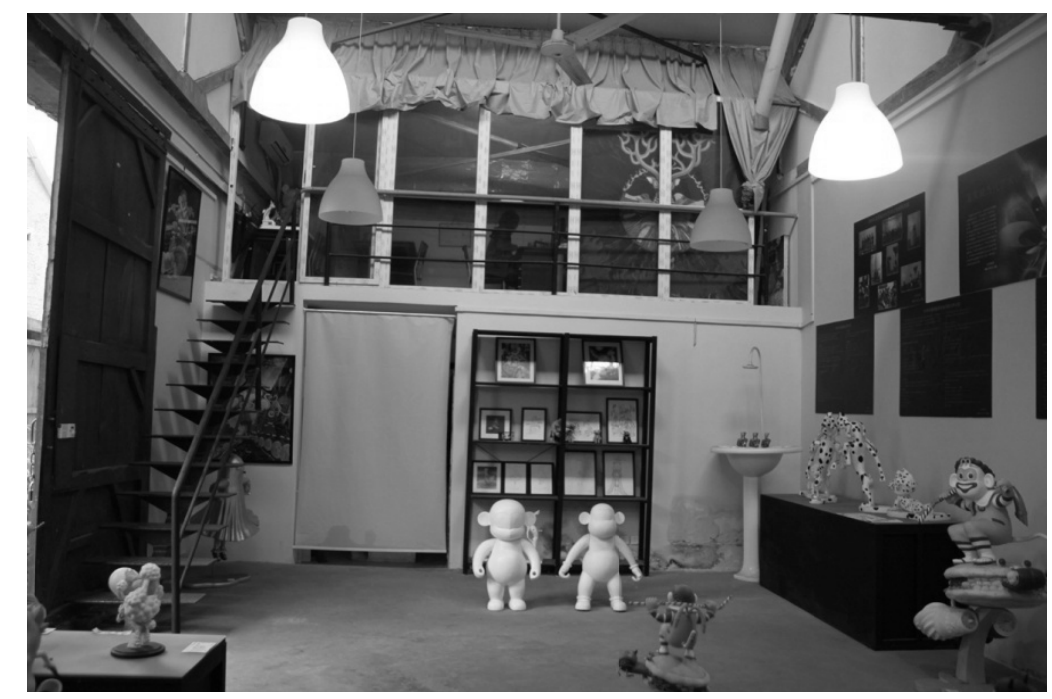

Figure 4. The Interior of an Art studio

Source: taken by author.

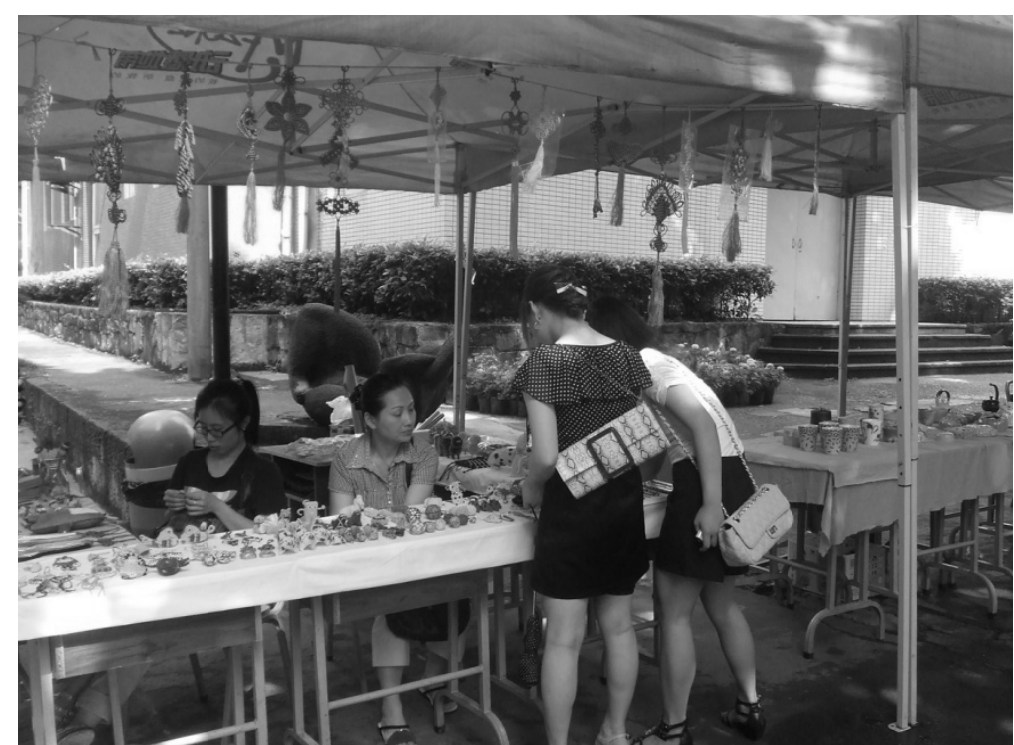

Figure 5. Example of the creative industry business in Huangjueping

Source: taken by Author.

\subsubsection{Building Renovations}

Chongqing Contemporary Arts Centre comprises a Tank-warehouse (Figure 5), the 501 Art bases (Figure 6), and some withheld original structures, warehouse features, and industrial plants. Parts of the reconstruction were also 
based on the old buildings and enhanced individual studio artistic style. Interior decorations demonstrated the artist's hobby and personality. The tank-warehouse in the centre's gallery was the representative works of architectural renovation in Huangjueping.

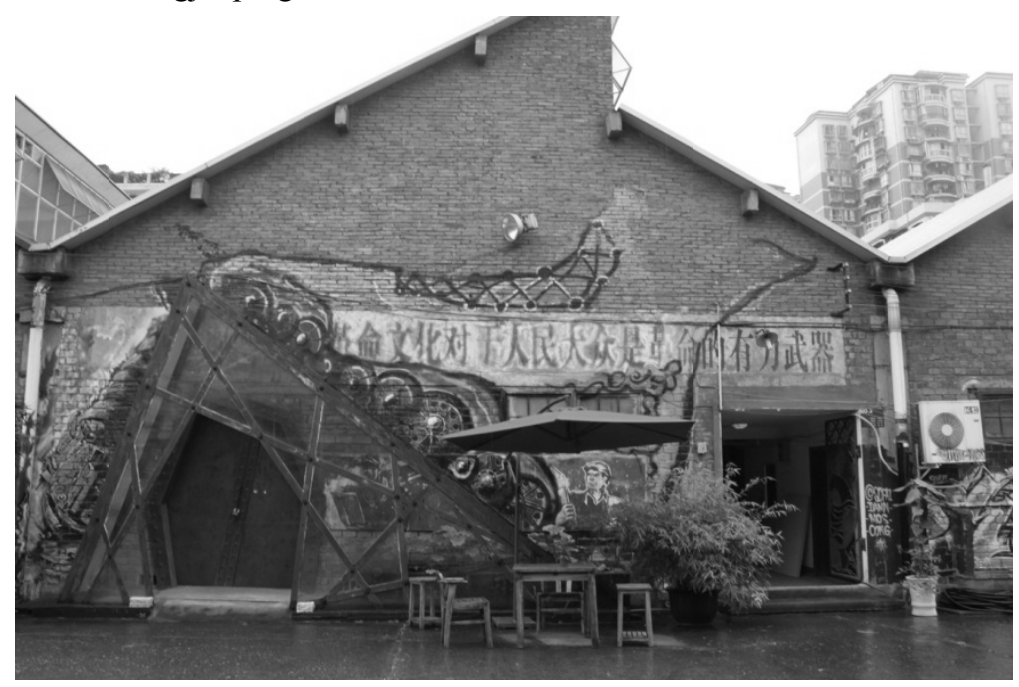

Figure 6. The Tank-warehouse. Chongqing Contemporary Arts Centre

Source: taken by author.

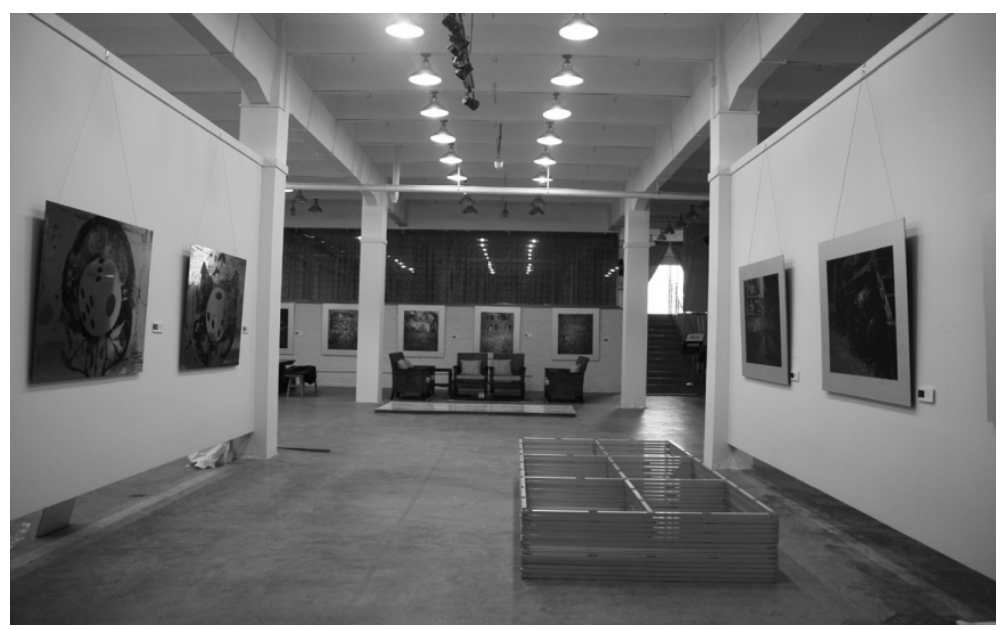

Figure 7. The 501 Art base

Source: taken by author.

The Tank-warehouse was a former military warehouse. Because there had been a tank leaving during the World War II, people always called it the Tank-warehouse. The renovation retained the original layout of the warehouse with re-modelling of some walls. The warehouse was divided into two parallel buildings with about 50 independent studios. In the middle was the channel with a width of about 10 metres.

The Tank-warehouse facade along the channel and retained the original style of: the bare bricks, the original steel pipe, slogans, and slope roof which all showed industrial architectural style of the 1950s - 1960s. Colourful graffiti pictures were common on the walls some of which were painted by foreign students. The channel set up a few small flower beds. The green of plants and the grey red of the buildings formed strong contrast, which made the warehouse much more ancient and massive. Another catchy design was the warehouse doors which had two types. The small doors were about 2.5 metres high and the bigger ones were about 3.6 metres high which were mainly made by hollow iron plates, steel, or glass with the amusing images such as that of the Peking Opera, or animals. The facades of Tank-warehouse management centre and the Contemporary Art Magazine were full of glass roof slope and the furnishings were looming as it made the old warehouse look much more modern. 


\subsection{Space Renewal and Inheritance of the Urban Context}

Liangyong $\mathrm{Wu}$, a Chinese professor of architecture and urban studies is reported to have said that each city has its own history, cultural traditions and development experience which together create its urban context (China Construction News, 2011). So the context is an important urban trait that distinguishes one city from the other as well as block from block.

Urban renewal encompasses a range of policies and determination to revitalize especially broken down old cities and mainstream them into the present generation of economic transformation. In many cases, it led to displacements where demolitions have been carried out, and in other cases, it provided opportunities for reintegration of old urban fabrics and economies into the new architectural and economics of urban development (see, for instance, O'Connor, 1993; Hyra, 2008). The seventy years history of Sichuan Fine Arts University makes Huangjueping one with a rich artistic resources and a unique urban context. The historical context of Huangjueping is not only the rich artistic atmosphere but also the industry culture. To this end, the renewal should remain and demonstrate those features.

Graffiti is a concrete manifestation of art, so the graffiti means art in people's cognitive system. A large area of graffiti art is a good way to create strong atmosphere. The forms, colours, bodies of the buildings all are art elements, so the renewed building of Huangjueping is not so much of architectural facades as that of other art products. The building renovation of the Tank-warehouse, Chongqing Contemporary Arts Centre and the 501 Art bases also used this style. In addition to the graffiti, other artistic forms such as sculpture, space and colour compositions are added which stresses the artistic originality and cultural content.

Also, cultural diversity in the Huangjueping streets is an important feature. The urban renewal promoted this cultural diversity well. Streets should be a leisure and communication place. As a result, barbecue booths and night beer stalls for example were removed to the larger and relatively fixed places. The street set up night market for selling clothing, stationery and creative products among others. The streets are always lights blazing and crowds pouring until 11 or 12:00 mid-night.

Further, the Huangjueping region has a strong industrial culture. The urban renewal emphasized the cultural elements: the gate of the Sichuan Fine Arts University used the large-scale steel tubes with an industrial symbol while the benches were made with iron pipes. In addition, there were eight sculptures modified with used machine parts in the street space. All of those are typical industrial cultural symbols.

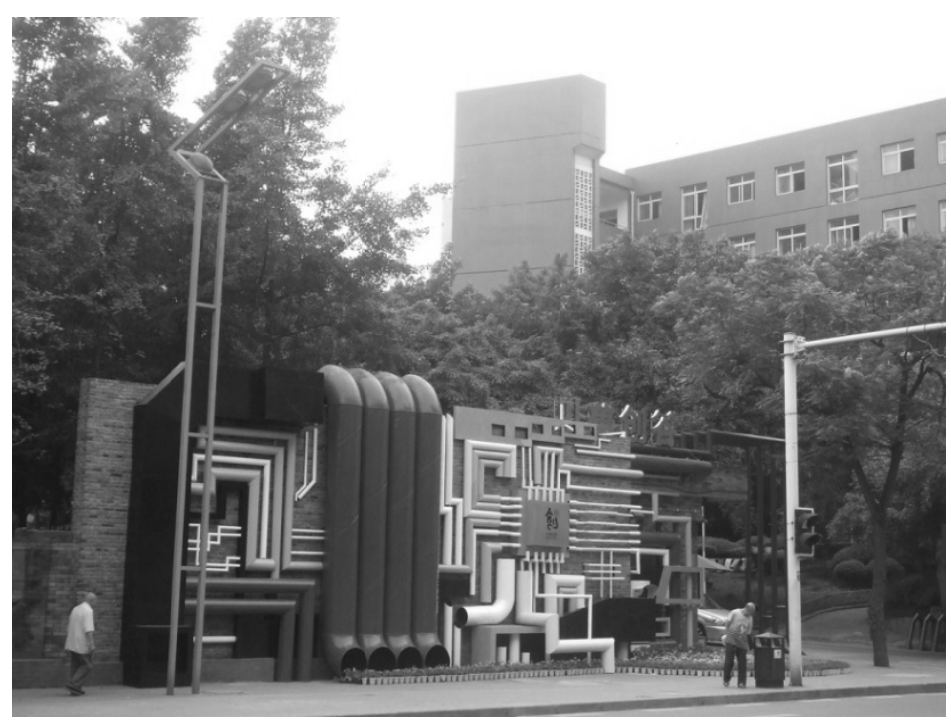

Figure 8. The gate of ChuanMei Creative Valley

Source: taken by author.

\section{General Discussion and Conclusion}

The accumulation of human resources plays an important role in economic development. Art and history as we saw, provide opportunities for sustainable improvements in urban economic structure. Culture as a new kind of urban resource has become a driving force of urban renewal. For instance, urban renewal in early to mid $20^{\text {th }}$ 
century involved if not entirely of demolitions and reconstruction (see, for instance, O'Connor, 1993). Experience from Huangjueping has shown that creative industries can integrate culture, creativity and economic development together. Renewing urban space through the creative industry has therefore become a new approach to urban design. Developing rationally and utilizing the city's unique resources, promoting the creative industry to bigger clusters are the new trend to achieving the city's urban renewal under the urban cultural context and developing sustainably in recent years.

Urban renewal by means of creative industries as a theme should emphasize the characteristics of blocks, combine the development of creative industries with the local industrial and consumption structures, integrating the development of creative industries with the historical and cultural heritage protection, continuing the city's context are the driving forces for urban development and the realization of urban economic growth in this era of urban land adjustments. A perfect design therefore is making every building and street as well as the whole city a work of art and a product of culture. Future research could focus on the financial aspects of cultural industries and their contribution to local economic development.

\section{References}

Caves, R. E. (2003). Contracts between Art and Commerce. The Journal of Economic Perspectives, 17(2), 73-83. http://dx.doi.org/10.1257/089533003765888430

China Construction News. (2011, September 20). Urban construction, where is your personality. Retrieved from China Construction News: http://www.chinajsb.cn/gb/content/2003-07/18/content_4279.htm

Chongqing Municipal Bureau of Statistics. (2011). Chongqing Statistical Yearbook 2011. Chongqing: China Statistics Press.

Chongqing Municipality. (2011). Communiqué on Major Data of the sixth national census of 2010. Chongqing: Municipality of Chonqqing. Retrieved from http://news.163.com/11/0503/01/733HTAIV00014AED.html

Drake, G. (2003). This Place gives me Space: Place and Creativity in the Creative Industries. Geofom: Elsevier.

Hyra, D. S. (2008). The New Urban Renewal: The Economic transformation of Harlem and Bronzeville. Chicago, USA: The University of Chicago Press.

Jianqiang, Y. (2004). The status, characteristics and trends of Chinese urban renewal. Urban planning, 53-63.

Jingfeng, C. (2008). The research of creative industry clustering spatial organization in Shanghai. Shanghai: East China Normal University.

O'Connor, J. (2012, March 20). The Definition of 'Cultural Industries'. Retrieved from http://www.pedrobendassolli.com/pesquisa/icc1.pdf

O'Connor, T. H. (1993). Building a New Boston: Politics and Urban Renewal 1950 to 1970. Boston, Massachusetts, USA: Northeastern University Press.

Porter, M. E. (2000). Location, Clusters and Company Strategy,. In G. L. Clark, The Oxford Handbook of Economic Geography (pp. 253-274). Oxford: Oxford University Press.

Qi, W. (2009). The nature and characteristics of creative industries. Journal of Gansu theory, 4, 113-115.

Qiang, L. (2007). The research of creative Industrial clusters developing around the university under the background of urban renewal -a Case Study of creative industries cluster around Tongji university. Shanghai: Tongji University Press.

Shouchang, H. (2006). The research of creative industries value. Shanghai: Shanghai Jiaotong University.

UNESCO. (2012, March 20). Understanding Creative Industries: cultural statistics for public-policy making. New York: United Nations Publishing. Retrieved from http://portal.unesco.org/culture/en/files/30297/11942616973cultural_stat_EN.pdf/cultural_stat_EN.pdf

Yanfei, X., Xiuning, C., \& Shuanghong, L. (2010). The Role of Creative Industry in Urban Development. Urban Problems, 98-112. 